\title{
Long-Term Trends in Conventional Political Participation in the Federal Republic of Germany*
}

\author{
Długookresowe trendy konwencjonalnej partycypacji politycznej \\ w Republice Federalnej Niemiec
}

\section{- Abstrakt •}

Celem badań była identyfikacja długookresowych trendów partycypacji konwencjonalnej w Republice Federalnej Niemiec. Ramy czasowe analiz objęly okres od 1946 do 2016 roku. Partycypacja konwencjonalna była mierzona dwiema zmiennymi: poziomem uczestnictwa wyborczego oraz poziomem członkostwa w partiach politycznych. Zarówno w przypadku pierwszej, jak i drugiej zmiennej wyodrębniono ważne statystycznie tendencje rozwojowe, głównie o charakterze spadkowym. W badaniach użyto analizy regresji. Posłużono się danymi dotyczącymi poziomu frekwencji wyborczej w wyborach do Bundestagu i do landtagów oraz danymi obrazującymi proces kształtowania się poziomu członkostwa w sześciu najistotniejszych partiach politycznych: CDU, SPD, CSU, FDP, Sojuszu 90/Zielonych oraz Lewicy/PDS.

Słowa kluczowe: partycypacja polityczna; działania konwencjonalne; trendy uczestnictwa; Republika Federalna Niemiec

\section{- Abstract •}

The purpose of this study was to identify longterm trends in conventional participation in the Federal Republic of Germany. The time frame for the analysis covered the period between 1946 and 2016. Conventional participation was measured against two variables using regression analysis: the level of participation in elections and the level of membership in political parties. For both variables, statistically significant development trends were identified, which were mainly of a declining nature. The data employed concerned voter turnout in elections to the Bundestag and Landtags, and the development process of membership levels in six major political parties: CDU, SPD, CSU, FDP, Alliance 90/ /The Greens, and the Left/PDS.

Keywords: political participation; conventional actions; participation trends; Federal Republic of Germany

* The article uses excerpts from the author's doctoral thesis - Partycypacja polityczna w Republice Federalnej Niemiec. Ujęcie ilościowe (2016). 


\section{Introduction}

In simple terms, political participation means the actions of citizens aimed at influencing politics (Van Deth, 2014, p. 351). This quite intuitive definition conceals a multitude of possible expressions of political participation. In fact, political participation can take various forms, often very different from one another. On the one hand, expressions of political participation include voting, party membership or, for example, donations to a party or candidate. On the other hand, individuals can participate in politics through activities such as occupation of government buildings, participation in unlawful demonstrations and, in extreme cases, political murder, or participation in revolution or civil war. On the basis of a superficial review of the aforementioned activities, we can already distinguish a classification criterion, according to which political participation can be divided into conventional and unconventional participation (see for example: Barnes \& Kaase, 1979; Dalton, 1988; Marsh, 1990; Westle, 1991; Gabriel, 1997; Garlicki, 2005; Strømsnes, 2009; Bee \& Kaya, 2017). Conventional political participation means acting in accordance with the legal and/or customary norms of a given political regime. Conversely, unconventional political participation includes activities that go beyond the legal order and/or customary norms governing interactions within the framework of complex networks of social relations in a given regime (Conway, 2000, pp. 3-4; Mider, 2008, p. 86). This article refers to this division but focuses only on conventional actions.

Researchers studying political participation in the Federal Republic of Germany often point to the existence of certain patterns of participation. Their work reveals a steady decline, particularly since the 1970s, of the level of conventional participation (see for example: Eilfort, 2006; Wiesendahl, 2006; Schäfer, 2009; Steinbrecher, 2009; Rucht, 2010). However, not all researchers build their concepts after the prior application of appropriate statistical tests showing the existence or non-existence of statistically important participation trends. Due to the above, the main goal of the study was to answer the question whether there were any developmental tendencies in conventional political participation in Germany in the period 1946-2016. If so, what were these tendencies and why did they occur? 


\section{Data and Methods}

Two forms of conventional political participation, i.e., electoral participation measured by the level of voter turnout and party membership, were analysed. The analysis considered the level of voter turnout for Bundestag and Landtags elections, as well as the level of membership in the CDU, SPD, CSU, FDP, Alliance 90/the Greens, and the Left/PDS. The limitation of the research to two activities, two types of elections and six political parties was dictated by the availability of a sufficient number of observations to provide a basis for regression analysis ${ }^{1}$. The data on voter turnout was obtained from the websites of the Federal Returning Officer (http://www.bundeswahlleiter.de/) and the Land Returning Officers (https://www.bundeswahlleiter.de/service/landtagswahlen.html). Data on the level of party membership is provided and updated by Oskar Niedermayer (2017, p. 2). Information can also be found in the book by Ulrich von Alemann, Philipp Erbentraut, \& Jens Walther (2010, p. 171). All statistical analyses were performed using Microsoft Office Excel 2013.

\section{Results}

\section{Electoral Participation}

Researchers of political participation and democratic systems of appointment of political representation believe that voting is the most important form of participation in politics for citizens and the system itself (Cześnik, 2007, p. 13; Rudzio, 2015, p. 175; Steinbrecher, 2009, pp. 111-112; Blais, 2010, p. 237; Dalton \& Klingemann, 2010, p. 42). It is thought to perform the following functions: articulation of political preferences, delegation of political representation, control over authorities, legitimisation of authorities, and political and social integration (Gabriel, 1997, pp. 435-436; Wojtasik, 2013, p. 28). It should also be noted that electoral participation is of great importance for political scientists, not least because public institutions are involved in measuring its level. They periodically provide empirical material without which the description, explanation and forecasting of political processes in democratic regimes would be much more difficult, particularly in the long run.

\footnotetext{
${ }^{1}$ Linear regression and second order polynomial regression models were fitted to the data.
} 
Analysing the data presented in Figure 1, we notice that for the Germans, parliamentary elections are the most important. Between 1949 and 2017, they went to the ballot boxes 19 times to appoint representatives to the Bundestag. Voter turnout rose gradually from $78.5 \%$ in 1949 to $86-87 \%$ in the 1950 s and 1960 s to reach a peak in the 1970 s $-91.1 \%$ in 1972 and $90.7 \%$ four years later. Since then, with periodic departures, its level has decreased. This regularity was particularly strong in the last decade of the twentieth century and in the first decade of the twenty-first century - below 80\%, including the all-time low of $70.8 \%$ in 2009. Regression analysis showed that the quadratic model is better fit for the data than the linear model. In the case of the linear model, the coefficients took the following values: $R^{2}=0.4649$, with $p=0.001302 ; b_{0}=488.17, b_{1}=-0.2044$. This means that $46 \%$ of the variance in voter turnout for Bundestag elections is explained by the variation in years. The remainder of the variance, i.e., 54\%, is explained by other factors, not included in the model. In turn, the slope coefficient $\left(b_{1}\right)$ took the value of -0.2044 . It is, therefore, expected that with the increase in the value of the predictor by one unit (one year), the value of voter turnout will decrease by 0.2044 percentage points. In the case of the quadratic model, the following coefficient values were obtained: $R^{2}=0.7269$, with $p=3.093 \mathrm{e}-05 ; b_{0}=-31879$, $b_{1}=32.443, b_{2}=-0.0082$. This means that as much as $73 \%$ of the variation in turnout in Bundestag elections is explained by the variation in years ${ }^{2}$.

Figure 1. Voter turnout for Bundestag (a) and Landtags (b) elections

(a)

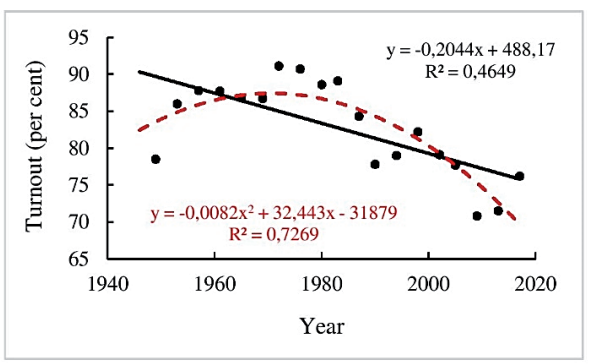

(b)

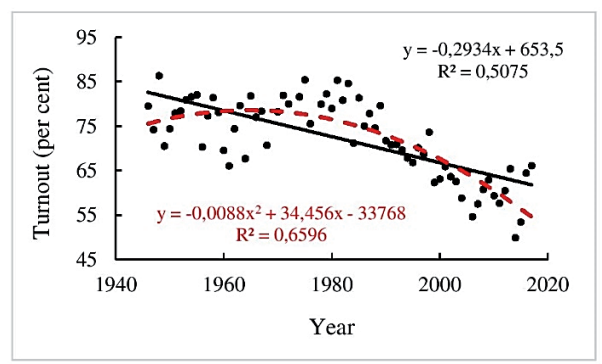

Source: author's own study.

2 Also on the basis of the partial F-test result, we can reject the zero hypothesis of no statistically significant differences between the models and assume that the quadratic model is a significantly better fit for the data than the linear model. The value of the test statistics was 15.349 and the corresponding $p$-value was 0.001227 . 
The turnout in regional elections was slightly lower. Until the 1990s, it oscillated between 70 and 85 percentage points, with a marked increase between 1970 and 1980. In the last 25 years, however, it has rarely exceeded $70 \%$, falling quite frequently below the $60^{\text {th }}$ percentage point. In 2014, it reached its minimum, i.e., $49.9 \%$. On the basis of the models obtained as a result of the calculations, we can predict the level of voter turnout with higher accuracy than based only on the arithmetic mean. As in the case of voter turnout for Bundestag elections, the quadratic model proved to be better suited to the data than the linear model. The coefficients for the linear model took the following values: $R^{2}=0.5075$, $p=6.692 e-12 ; b_{0}=653.5, b_{1}=-0.2934$, and for the quadratic model: $R^{2}=0.6596$, $p=3.605 \mathrm{e}-16 ; b_{0}=-33768, b_{1}=34.456, b_{2}=-0.0088^{3}$.

\section{Party Membership}

Several important periods can be distinguished in the evolution of German political parties (and, really, the German party system in general) since 1945 . We refer to Alemann, Erbentraut, \& Walther (2010, pp. 46-96), who proposed a five-phase periodisation:

1. The formation phase, occurring in the years 1945-1953 - the CDU was established at that time, the SPD was reactivated, and the Free Democratic Party (FDP) was established; ten groups entered the Bundestag as a result of the 1949 elections;

2. The concentration phase in the years 1953-1976 - after the electoral reform $^{4}$, the CDU, CSU, SPD and FDP gained a clear advantage; in the elections of 1972 and 1976 these parties won a total of $99.1 \%$ of votes;

3. The transformation phase in the years 1976-1994 - the Green Party emerged, which received 5.6\% and 8.3\% of the votes in 1983 and 1987, respectively; the process of integration of eastern political structures with the West German system began (The Party of Democratic Socialism - PDS was established as the heir to the Socialist Unity Party of Germany - SED); a five-party system was formed: The Union, SPD, FDP, PDS, and Alliance

3 The value of the partial F-test statistics was 29.491 and the corresponding p-value was 8.682e-07.

${ }^{4}$ Since the 1953 elections, each voter has been entitled to two votes: the first is cast directly for a candidate in one of the 299 single-member districts, while the other supports a party list. Also in 1953, the requirement to obtain 5\% of these "second votes" on a national scale was introduced (Von Beyme, 2010, p. 91). 
90/the Greens; at the end of this period, party identification declined significantly; while in the 1970 s more than $50 \%$ of voters declared a strong identification with political parties, this level decreased to about $40 \%$ in the mid-1990s;

4. The stabilisation phase in the years 1994-2002 - the main political forces tried to appeal to the moderate electorate, thus distancing themselves from compromised ideologies;

5. The "fluid" phase since 2002 - support for the people's parties decreased significantly, while confidence in the Left and the Greens increased - this process lasted until 2009; during this time, voter turnout was reduced to its lowest level since 1949; a new citizens' initiative, The Pirate Party Germany, was launched; as a result of the 2013 elections, the middle-class FDP found itself for the first time outside the Bundestag, and after the 2017 elections, representatives of the nationalist AfD won seats in the Bundestag.

The period of transition from the concentration phase to the transformation phase, during which events with significant consequences for the German political system occurred, is particularly important for this study. The increased activity of the Red Army Faction (RAF), which led to a serious crisis in the state (German Autumn), is one of the issues under consideration. An atmosphere of fear and threat has been scrupulously exploited by those mobilising to participate in politics. At that time, the highest level of voter turnout in Bundestag elections since 1945 and the highest level of membership in political parties, especially people's parties, were recorded. In the following decades, the level of political commitment of the Germans expressed in conventional forms of political participation decreased (with periodic departures from the trend). Figure 2 illustrates the process of shaping the level of party membership in the period 1947-2016. 
[43]

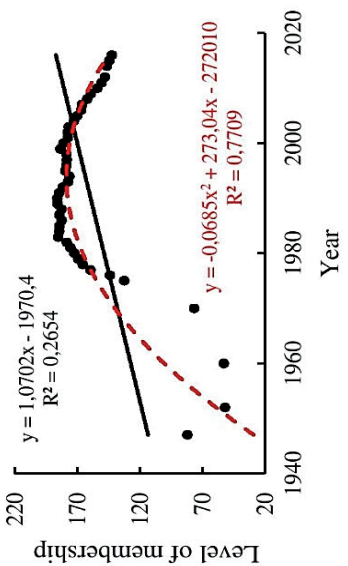

อ

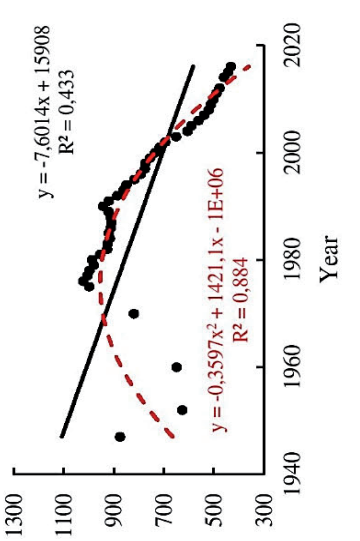

a

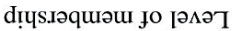

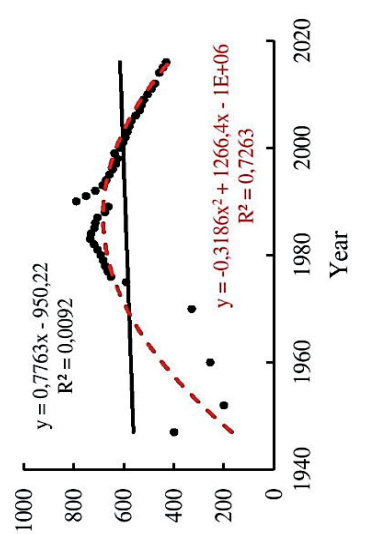

ङ

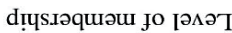

$\oplus$

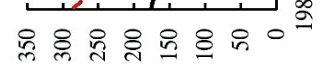

d!̣ร.әәчиәш јо [әләา

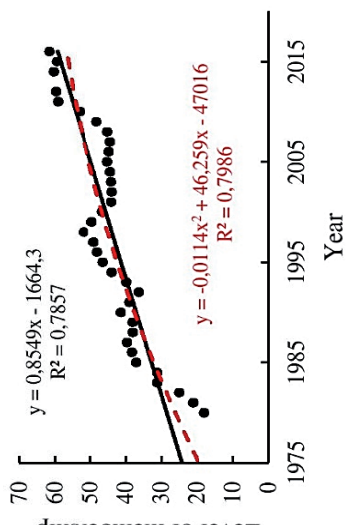

e d!̣s.ıәшәш јо [әкә]

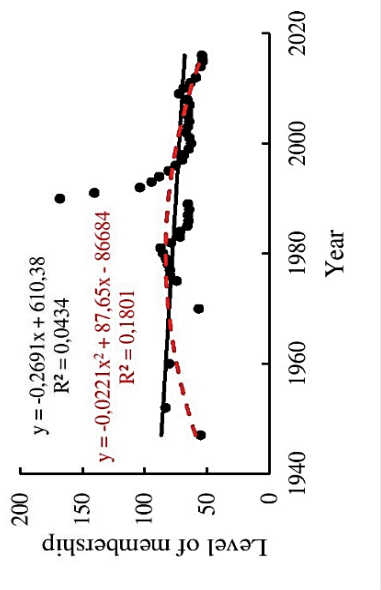


Analyses of the data presented in Figure 2 show that the two largest parties, i.e., SPD and CDU, witnessed a decrease in membership from about 1 million in the first party (1970s) and from about 800 thousand in the second party (early 1990s) to about 450 thousand today. Analyses prepared for SPD show that the quadratic model fits much better to the data than the linear model. For the linear model, the coefficients took the following values: $R^{2}=0.443, p=9.015 \mathrm{e}-07$; $b_{0}=15908, b_{1}=-7.6014$, and for the quadratic model: $R^{2}=0.884, p<2.2 e-16$; $b_{0}=-1.403 \mathrm{e}+06, b_{1}=1421.1, b_{2}=-0.3597^{5}$. Upon applying the same procedures to the level of membership in CDU, the following values of coefficients were obtained: for the linear model: $R^{2}=0.0092, p=0.5319 ; b_{0}=-950.22, b_{1}=$ $=0.7763$, and for the quadratic model: $R^{2}=0.7263, p=1.525 \mathrm{e}-12 ; b_{0}=-1.258 \mathrm{e}+06$, $b_{1}=1266.4, b_{2}=-0.3186^{6}$. As in the case of membership in SPD, the quadratic model proved to be better suited to the data than the linear model. In addition, membership trends are also observed in CSU (declining since the 1980s) and in the Left/PDS (declining). In the case of FDP, neither a linear nor a quadratic dependence was observed, while in the case of the Greens, there is an upward trend.

\section{Summary and Discussion}

Analyses have shown that in the Federal Republic of Germany, in the years 1946-2016, developmental tendencies of conventional political participation could be observed. These concerned the level of electoral participation and the level of party membership. For the former, both parliamentary and regional elections showed a downward trend (since the 1970s and 1980s). The situation was similar in the case of the latter. The level of membership in people's parties, CSU and the Left/ /PDS, was decreasing, in FDP there was no statistical dependence, while there was an upward trend in the case of the Greens.

Attempts to explain the studied phenomena in a reliable way prove rather difficult. Which processes should, therefore, be seen as a determinant of the decrease in the level of participation through conventional behaviours? Here, we can indicate at least three hypotheses:

1. Normalisation hypothesis - in the opinion of a group of researchers supporting this explanation, the decrease in the level of voter turnout, as well as the decrease in the level of membership in people's parties, are not symp-

\footnotetext{
5 The value of the partial F-test statistics was 163.3 and the corresponding $p$-value was 4.601e-16.

${ }^{6}$ The value of the partial F-test statistics was 110.04 and the corresponding $p$-value was $2.638 \mathrm{e}-13$.
} 
toms of a democratic crisis, but a return to "normality" after the peak phase of political mobilisation in the 1970 s;

2. Satisfaction hypothesis - some political scientists believe that the decrease in the level of conventional participation is a consequence of the progressive satisfaction of citizens with the work of the government and their deep identification with its activities ${ }^{\top}$;

3. Participation transfer hypothesis - in this perspective, the growing social and political awareness of citizens determines attitudes discouraging them from traditional channels of interest articulation (no longer fulfilling the hopes placed in them, e.g., implementation of the demands of social equality or justice) towards less formal and bureaucratic channels, hence the alleged shift in participation towards unconventional behaviours (see: Schäfer, 2009, pp. 33-38).

The truthfulness of only one of the above hypotheses seems unlikely. It cannot be ruled out, however, that some individuals who do not participate in politics through conventional forms are content with the situation in the state, while others have shifted their activity to unconventional behaviours, and others do not participate, because the mobilising entities no longer strive for this as much as they did in the 1970s and 1980s. Notwithstanding the above, there is no doubt that one characteristic feature of the proposed explanations is their highly speculative character. They are usually supported by rather poor data, which can be interpreted in many ways.

\section{References:}

Arzheimer, K. (2002). Politikverdrossenheit. Bedeutung, Verwendung und empirische Relevanz eines politikwissenschaftlichen Begriffes. Wiesbaden: VS Verlag für Sozialwissenschaften. DOI: https://doi.org/10.1007/978-3-322-97103-6.

Barnes, S.H., \& Kaase, M. (1979) (eds.). Political Action: Mass Participation in Five Western Democracies. Beverly Hills: Sage Publications.

Bee, C., \& Kaya, A. (2017). Conventional Versus Non-Conventional Political Participation in Turkey: Dimensions, Means, and Consequences. Turkish Studies, 18(1), 1-9. DOI: https://doi.org/10.1080/14683849.2016.1272049.

7 The factors determining the decline in the level of conventional participation could equally well be seen in such intervening variables as: political apathy manifested by reduced activity, or a feeling of discouragement transforming into a negative attitude towards political activity and political structures, which results not so much in lack of interest, but in a rejection of politics and the possibility of participating in it (see: Di Palma, 1970, p. 208; Arzheimer, 2002, pp. 32-40). 
Blais, A. (2010). Frekwencja wyborcza. In: R.J. Dalton, \& H.D. Klingemann (eds.). Zachowania polityczne. Vol. 2 (pp. 237-256). Warszawa: Wydawnictwo Naukowe PWN.

Conway, M.M. (2000). Political Participation in the United States. Washington, D.C.: CQ Press.

Cześnik, M. (2007). Partycypacja wyborcza w Polsce. Perspektywa porównawcza. Warszawa: Wydawnictwo Naukowe Scholar.

Dalton, R.J. (1988). Citizen Politics in Western Democracies: Public Opinion and Political Parties in the United States, Great Britain, West Germany, and France. Chatham, N.J.: Chatham House Publishers.

Dalton, R.J., \& Klingemann, H.D. (2010). Obywatele a zachowania polityczne. In: R.J. Dalton, \& H.D. Klingemann (eds.). Zachowania polityczne. Vol. 1 (pp. 33-62). Warszawa: Wydawnictwo Naukowe PWN.

Di Palma, G. (1970). Apathy and Participation: Mass Politics in Western Societies. New York: The Free Press.

Eilfort, M. (2006). Wahlenthaltung: Ein vielschichtiges Phänomen mit wachsender politischer Bedeutung. In: B. Hoecker (ed.). Politische Partizipation zwischen Konvention und Protest. Eine studienorientierte Einführung (pp. 55-73). Opladen: Verlag Barbara Budrich.

Gabriel, O.W. (1997). Politische Einstellungen und politisches Verhalten. In: O.W. Gabriel, \& E. Holtmann (eds.). Handbuch Politisches System der Bundesrepublik Deutschland (pp. 381-497). München-Wien: R. Oldenbourg.

Garlicki, J. (2005). Demokracja i integracja europejska. Studium osobistych i politycznych orientacji dwóch pokoleń Polaków. Toruń: Wydawnictwo Adam Marszałek.

Marsh, A. (1990). Political Action in Europe and the USA. Basingstoke: MacMillan.

Mider, D. (2008). Partycypacja polityczna w Internecie. Studium politologiczne. Warszawa: Dom Wydawniczy Elipsa.

Niedermayer, O. (2017). Parteimitglieder in Deutschland: Version 2017 NEU. Arbeitshefte aus dem OSZ, 27, 1-82. Retrieved from: https://www.polsoz.fu-berlin.de/ polwiss/forschung/systeme/empsoz/team/ehemalige/Publikationen/schriften/Arbeitshefte/P-PMIT17-NEU.pdf.

Rucht, D. (2010). Engagement im Wandel: Politische Partizipation in Deutschland. WZBrief Zivilengagement 01. Berlin: Wissenschaftszentrum Berlin für Sozialforschung (WZB). Retrieved from: https:/www.econstor.eu/bitstream/10419/60046/1/631896406.pdf.

Rudzio, W. (2015). Das politische System der Bundesrepublik Deutschland. Wiesbaden: VS Verlag für Sozialwissenschaften. DOI: https://doi.org/10.1007/978-3-658-06231-6.

Schäfer, A. (2009). Alles halb so schlimm? Warum eine sinkende Wablbeteiligung der Demokratie schadet. Köln: Max Planck-Institut für Gesellschaftsforschung. Retrieved from: http://www.mpifg.de/aktuelles/themen/doks/jahrbuch-09-10-schaefer-280509. pdf.

Steinbrecher, M. (2009). Politische Partizipation in Deutschland. Baden-Baden: Nomos Verlagsgesellschaft.

Strømsnes, K. (2009). Political Consumerism: A Substitute for or Supplement to Conventional Political Participation? Journal of Civil Society, 5(3), 303-314. DOI: https://doi. org/10.1080/17448680903351834. 
Van Deth, J.W. (2014). A Conceptual Map of Political Participation. Acta Politica, 49(3), 349-367. DOI: https://doi.org/10.1057/ap.2014.6.

Von Alemann, U., Erbentraut, P., \& Walther, J. (2010). Das Parteiensystem der Bundesrepublik Deutschland. Wiesbaden: VS Verlag für Sozialwissenschaften. DOI: https://doi. org/10.1007/978-3-658-21159-2.

Von Beyme, K. (2010). Das politische System der Bundesrepublik Deutschland. Eine Einführung. Wiesbaden: VS Verlag für Sozialwissenschaften. DOI: https://doi. org/10.1007/978-3-531-92567-7.

Wajzer, M. (2016). Partycypacja polityczna w Republice Federalnej Niemiec. Ujęcie ilościowe. Unpublished Dissertation. Katowice.

Westle, B. (1991). Politische Legitimität und politische Partizipation in der Bundesrepublik Deutschland der Achtziger Jahre. In: G. Meyer, \& F. Ryszka (eds.). Political Participation and Democracy in Poland and West Germany (pp. 82-133). Warszawa: Ośrodek Badań Społecznych.

Wiesendahl, E. (2006). Partizipation in Parteien: Ein Auslaufmodell? In: B. Hoecker (ed.). Politische Partizipation zwischen Konvention und Protest. Eine studienorientierte Einführung (pp. 74-99). Opladen: Verlag Barbara Budrich.

Wojtasik, W. (2013). Functions of Elections in Democratic Systems. Political Preferences, 4, 25-38. 